\title{
Appeasing company owners through effective working capital management
}

\author{
Salla Marttonen, Sari Viskari, Timo Kärri \\ Department of Industrial Management, Lappeenranta University of Technology \\ P.O. Box 20, FIN-53851 Lappeenranta, Finland \\ salla.marttonen@lut.fi \\ sari.viskari@lut.fi \\ timo.karri@lut.fi
}

[Author 1 bio] Salla Marttonen (M.Sc.) is a doctoral student in the Department of Industrial Management at Lappeenranta University of Technology, Finland. She received her M.Sc. (Tech.) in Industrial Management in 2010 and after that she has worked in academia. Her research interests include capital, capacity and cost management. Her doctoral studies are related to costs and profitability of industrial maintenance business.

[Author 2 bio] Sari Viskari (M.Sc.) is a doctoral student in the Department of Industrial Management at Lappeenranta University of Technology, Finland. She received her M.Sc. (Tech.) in Industrial Management in 2006 and after that she has worked in private sector as well as in academic world. Her research interests include capital, capacity and cost management. Her doctoral studies are related to financial supply chain management and accounting in networks, more specifically measuring and management of working capital.

[Author 3 bio] Timo Kärri is a professor (acting) in the Department of Industrial Management at Lappeenranta University of Technology, Finland. He received his D.Sc. (Tech) in Industrial Management in 2007. His dissertation considered timing of capacity changes in capital intensive industries, and his research interests include capital, capacity and cost management. 


\title{
Appeasing company owners through effective working capital management
}

\begin{abstract}
In the dynamic financial climate of the present day, companies should be aware of the potential of effective working capital management in reacting to market transformations. It is important to include the company owner's viewpoint in the research perspective. In this paper, we study the connection between working capital management and the return on equity. The managerial and financial perspectives of flexible asset management are integrated through analytical modelling. We conclude that the return on equity can be improved by shortening the cycle time of operational working capital. Both the interest rate of debt and the debt-to-equity ratio are taken into account in order to study the effects of dynamic financial conditions. Changes in the financial conditions could be compensated through effective management of working capital.
\end{abstract}

Keywords: Working capital, Return on equity, Interest rate of debt, Debt-to-equity ratio, Modelling, Flexible asset management.

\section{Introduction}

In dynamic operating conditions and under the influence of uncertain demand, companies need to manage their balance sheets and assets flexibly. There are two different aspects of flexible asset management; firstly, the investments and divestments of a company's fixed assets should be integrated with the changes of demand. Secondly, the amount of working capital should be managed actively, at the same time considering the present and future demand, as well as the more general economic conditions (Ojanen et al., 2012). The amount of fixed assets has often been linked to the studies of return on capital, whereas the role of working capital has remained somewhat obscure to the general public. In this paper, the focus is on the working capital side of flexible asset management. The paper discusses the operational working capital, defined as inventories plus accounts receivable less accounts payable. Managing operational working capital means balancing the amount of capital tied into the operations. Simultaneously, the negative consequences of too small an amount of working capital on company liquidity must be taken into account.

Traditionally, working capital management has interested the research of corporate finance from the perspective of investments and liquidity. In recent years, also a more operational view to working capital management has emerged. The cycle time of working capital, called the cash conversion cycle $(C C C)$, has been recognized as an important measure of efficiency in operations management. The $C C C$ is also known in the 
literature as the cash-to-cash $(C 2 C)$ cycle. Previous literature has concluded that by shortening the $C C C$, a company can improve its return on invested capital (ROI) (e.g. Deloof, 2003; Shin and Soenen, 1998; Talha, Christopher, and Kamalavalli, 2010; Viskari, Pirttilä, and Kärri, 2011). There is a research gap in the discussion of the financial aspect of working capital management: the perspective of company owners. It is crucial for companies to keep their owners satisfied. This is highlighted in the dynamic financial conditions under which companies operate. Improved working capital management is one of the possible ways of increasing the value of the return on equity. Some initial ideas about connecting the financing position and the weighted average cost of capital (WACC) to working capital management can be found in the literature (Hofmann and Kotzab, 2010), but more research is needed to understand the connection between the costs of capital, capital structure, and working capital management of a company. The research questions of the paper are the following:

- How are the return on equity and working capital management connected?

- How does an increase in the interest rate of debt and in the debtto-equity ratio affect the return on equity, and can this effect be compensated with effective working capital management?

The paper offers two main contributions. First, it untangles the connection between the cycle time of operational working capital and the return on equity. Second, the discussion is extended to include also the cost of debt and the debt-to-equity ratio. All in all, we provide company owners with a way to analyze the importance of working capital management in dynamic financial conditions. Theories of asset and working capital management, corporate finance, and capital structure are integrated into a novel schema, which is verified with empirical data.

The structure of the paper is the following: after the introduction, the research design is presented. Next, working capital management in dynamic financial conditions is discussed through previous studies. After that we introduce our conceptual model, in addition to our financial extension of a previous model for flexible asset management. The verification of the extended model with financial statement data is presented in the subsequent section. The paper finishes with conclusions. 


\section{Research design}

Analytical modeling is used as the research method in this paper. This method is about using a deductive logic in representing a concept or a process (Demski, 2007). Modeling leads to high internal validity due to its transparency. In this paper, the flexible asset management (FAM) model developed by Marttonen, Viskari, and Kärri (2011) is expanded to include the financial perspective in addition to the managerial one. The model has been previously used to examine working capital management and ROI. We focus on modeling the connection between company return on equity and working capital management, taking into account the cost of debt and the debt-to-equity ratio. Our conceptual framework, as well as the extended FAM-model, is presented in section 4 of this paper.

The extended model is verified with empirical data from the Finnish industrial maintenance sector. This sector of industrial services is optimal for the verification of the model: previous literature has indicated that the importance of active working capital management is emphasized in industrial maintenance companies (Marttonen, Viskari, and Kärri, 2011). This is caused by their exceptionally small amount of fixed assets, compared to for example traditional manufacturing industrial companies. In addition, the discussion on industrial maintenance has escalated due to increased maintenance outsourcings, more and more complex industrial production equipment, and an extensive transition from corrective maintenance to preventive maintenance.

The verification of the model has been done with the financial statements of 18 Finnish industrial maintenance companies. Though small, the analyzed sample represents a remarkable share of the Finnish industrial maintenance sector. The 3893 persons employed by these 18 enterprises cover approximately $26 \%$ of the employees of the whole sector. The net sales of 472 million euro of the sample, on the other hand, represent approximately $13 \%$ of the sum used in industrial maintenance in Finland annually (Finnish Maintenance Society, 2007). The enterprises selected to the sample are listed in the Appendix, together with their personnel numbers and net sales. The sample has been selected by utilizing the membership list of the Finnish Maintenance Society. Structurally the sample represents the Finnish industrial maintenance sector well, consisting of a few large enterprises but mostly SMEs. The sample has been divided into five large enterprises and 13 SMEs according to the European Commission recommendation 2003/361/EC (European Commission, 2009). Maintenance companies from outside 
Finland have been excluded from the study because the required data was not within reach.

It was considered important that the sample would reflect especially the features of the industrial maintenance business. Thus, when selecting the sample, only enterprises whose focus was mainly on industrial maintenance were accepted, which means that equipment manufacturers and enterprises offering infrastructural maintenance services were delimited from the sample. Also the smallest micro enterprises were left out of this research. The period of analysis was 2004-2009. At the time of collecting the data, the financial statements of subsequent fiscal years were not yet available through the chosen database. The financial statement data was collected using the Voitto+ database (ISSN 14599457). This database is maintained by Suomen Asiakastieto Oy (loose translation Finnish Customer Information), which is a leading service enterprise in Finland, providing corporate information broadly considered to be reliable and objective.

\section{Literature review}

After having introduced our research design in the section above, we will now discuss the previous literature on the topic. This paper highlights the importance of active working capital management on a company level, especially from the company owner's perspective. Previous literature on these aspects is here integrated with the research of capital structure.

In the dynamic conditions of the present day, the importance of flexible management of the balance sheet is emphasized. Flexible asset management includes active controlling of both fixed assets and working capital. We concentrate on working capital in this paper. The focus is on managing the return on equity through the cycle time of working capital. Several large statistical studies have shown a negative connection between the $C C C$ and the relative profitability ROI (e.g. Deloof, 2003; GarcíaTeruel and Martínez-Solano, 2007; Shin and Soenen, 1998; Talha, Christopher, and Kamalavalli, 2010; Viskari, Pirttilä, and Kärri, 2011; Wang, 2002). This finding has been supported by Marttonen, Viskari, and Kärri (2011) with analytical modelling. Some studies have suggested that companies can boost their sales with generous credit terms and secure the service level with larger inventories (Blinder and Maccini, 1991; Deloof and Jegers, 1996; Shah, 2009). However, the positive effects of a large amount of working capital have been outdone by the traditional view: working capital increases the invested capital and decreases profitability. 
Even though the relation between the $C C C$ and the $R O I$ has been examined a lot, not many studies embody the owners' perspective in the discussion. In the company valuation literature, working capital has been linked to the cost of capital and the company owners' perspective. For example Black, Wright, and Bachman (1998) present a free cash flow model of company shareholder value, in which the growth of working capital and fixed assets has a negative impact on future cash flows. Yet, Black, Wright, and Bachman assume that the ratio of working capital to the net sales is constant, and they do not discuss the active management of this ratio. On the other hand, some financial variables have been included in the statistical analysis, but they have not been analyzed extensively. Filbeck, Krueger, and Preece (2007) have found some evidence that shareholders do recognize efficient working capital management. They have studied the stock market returns (dividends and capital gains) and the efficiency of working capital management. Lambert and Pohlen (2001) have presented both fixed assets and the elements of working capital as a part of the formation of economic value added. Still, working capital is not in the focus of their research. Losbichler, Mahmoodi, and Rothboeck (2008) have continued from the work of Lambert and Pohlen. They have focused on working capital in creating shareholder value. In this paper, we contribute to this discussion by modeling the connection between the $C C C$ and the return on equity explicitly.

The impact of uncertain financial conditions is taken into account here by discussing the company capital structure and the cost of capital. The relation between the debt-to-equity ratio and the interest rate of debt has inspired a long-lasting debate in the academic literature. The traditional view states that an optimal debt-to-equity ratio can minimize the cost of capital; debt-financing is beneficial to a company if not taken too far. However, beyond this optimum, the interest rate of debt starts to increase, and the growth of required return on equity accelerates, both factors causing a decrease in company value (Brealey, Myers, and Allen, 2008). This traditional theory was challenged by Modigliani and Miller (1958), who stated that the capital structure of a company affects neither its market value nor its average cost of capital. There is an underlying assumption of perfect capital markets in this theory, but nonetheless, the view of Modigliani and Miller has received extensive support in academia.

Previous literature about managing the debt-to-equity ratio is abundant. Eriotis, Vasiliou, and Ventoura-Neokosmidi (2007) bring forth the fact that there are various theories present in the capital structure research. The main theories include e.g. the tradeoff theory, the pecking order theory, and the agency theory, all of which are supported by empirical results (e.g. 
Eriotis, Vasiliou, and Ventoura-Neokosmidi, 2007; Harris and Raviv, 1991; Jensen and Meckling, 1976; Kayhan and Titman, 2007). The tradeoff theory states that there is an optimal, company-dependent capital structure to be found to maximize the firm value (Graham and Harvey, 2001; Hull, 2011; Kayhan and Titman, 2007; Leary and Roberts, 2005; Parsons and Titman, 2008; Stretcher and Johnson, 2011). This way of thinking has been adopted by many company managers, as it encourages to reasonable incurring of debt-financing. During economic downturns, the application of financial theories should be done with specific care. For example, it should be remembered that the optimal capital structure of a company is dynamic by nature, and the optimum changes according to the financial conditions.

\section{Extending the flexible asset management model to include the financial view}

The literature review above reveals that previous studies have recognized the relevance of working capital management to profitability. So far the owner's viewpoint has been linked to working capital in the literature of company valuation. However, the control perspective of this relation still remains unexplored. Previous research has not tried to manage working capital while considering the company owner's interests. The potential of working capital management under different costs of capital and capital structures has not been studied before, either. The financial conditions for companies are getting more volatile. This creates a need for companies to develop novel resorts to succeed in the competition. Working capital management could be one of these resorts. Figure 1 shows our conceptual framework describing the connection between working capital and the return on equity.

\section{$<$ Figure 1 here >}

The relations between the parameters of Figure 1 are presented mathematically in the flexible asset management (FAM) -model. The equations of the model are presented in the next paragraphs. Working capital is modeled through the cycle time of operational working capital, the $C C C$. Working capital is regarded more comprehensible when discussing the cycle times rather than monetary sums of working capital. The other components of net working capital are taken into the model through a residual term $(r)$, as our focus is on the operational working capital. The fixed assets are modeled through two different ratios: the first 
one compares the amount of fixed assets to the amount of net sales $(F A \%)$, and the second presents the average depreciation time of the fixed assets $(B)$. Relative measures like these are preferred over absolute monetary measures, for they enable comparison between companies. The profits are inspected with the profit margin ratio $(E B I T D A \%)$. This way the depreciations can be analyzed separately, with relation to the fixed assets. The relative profitability is modeled with the ROI, which is one of the most well-known measures for profitability (see e.g. Joshi, Kumar, and Al-Ajmi, 2011). On the financial side of Figure 1, the return on equity is simple to derive into the model from the ROI. Finally, examining the return on equity requires including the cost of debt, as well as the amount of debt and equity into the model.

The starting point for the modeling is the FAM-model, introduced by Marttonen, Viskari, and Kärri (2011). This model links the cycle time of operational working capital, the cash conversion cycle, to the ROI. Equation (1) presents the FAM-model.

$$
R O I=\frac{E B I T D A \%-\left(F A \% \times \frac{1}{B-1}\right)}{\frac{C C C}{365}+\frac{r}{365}+F A \%},
$$

where

$\begin{array}{ll}\text { ROI } & \text { is the return on investment, } \\ \text { EBITDA\% } & \begin{array}{l}\text { is the profit margin ratio, } \\ \text { is the amount of fixed assets relative to the } \\ \text { net sales, } \\ \text { is the average depreciation time (in years) of } \\ \text { fixed assets, } \\ \text { is the cycle time of operational working } \\ \text { capital, } \\ \text { is the residual term, consisting of other } \\ \text { current assets and other current liabilities. }\end{array}\end{array}$

We now extend this model by incorporating the cost of capital, consisting of both the interest rate of debt and the return on equity, into the model. The extension is based on the assumption that the ROI consists of the interest rate of long-term debt and the required return of equity (see Equation (2)). In this model, current liabilities and taxes are omitted. Through these definitions, a valid, straightforward connection between the cost of capital and the ROI can be constructed. The cost of capital can thus be determined as 


$$
i=\frac{i_{D} \times D+i_{E} \times E}{D+E}
$$

where

$i$
$i_{D}$
$i_{E}$
$D$
$E$

is the cost of capital,

is the average interest rate of long-term debt, is the return on equity, is the amount of long-term debt, is the amount of shareholder equity.

On the other hand, in a long term, a company's target return on invested capital should be set equal to the company cost of capital. Thus, by merging Equations (1) and (2), we get

$$
\frac{E B I T D A \%-\left(F A \% \times \frac{1}{B-1}\right)}{\frac{C C C}{365}+\frac{r}{365}+F A \%}=R O I=\frac{i_{D} \times D+i_{E} \times E}{D+E} .
$$

The left side of Equation (3) represents the managerial view of the FAM-model, whereas the right side of the Equation describes our extension, which highlights the owner's viewpoint. To observe the owner's view, $i_{E}$ can be defined as

$$
i_{E}=\frac{E B I T D A \%-\left(F A \% \times \frac{1}{B-1}\right)}{\frac{C C C}{365}+\frac{r}{365}+F A \%} \times\left(1+\frac{D}{E}\right)-i_{D} \times \frac{D}{E} .
$$

It can be concluded from Equation (4) that the return on equity increases if, ceteris paribus, the profit margin ratio or the average depreciation period increases, or if the fixed asset ratio, the cycle time of operational working capital, the residual term, or the interest rate of debt decreases. When the ROI is greater than $i_{D}$, an increase in the debt-toequity ratio causes an increase in the return on equity. On the other hand, when the $R O I$ is less than $i_{D}$, the debt-to-equity ratio should decrease for the return on equity to increase. This duality is known as financial leverage. If the $C C C$ is observed, the Equation can be written as:

$$
C C C=\frac{365 \times\left(E B I T D A \%-\left(F A \% \times \frac{1}{B-1}\right)\right)}{\left(i_{D} \times D+i_{E} \times E\right) /(D+E)}-365 \times F A \%-r .
$$


In this format, the model could be used to determine the objectives for working capital management. Companies often have target levels for profitability and the cost of capital. In Equation (5) these are represented by the EBITDA\% and the expression in the denominator. The $F A \%$, the $B$, and the $r$ could be set constant. On the other hand, if the focus is on the management of the fixed assets, the Equation could be solved for the $F A \%$, and the $C C C$ could be set constant. The model can thus be applied to various situations concerning asset management, company profitability, and financing issues.

\section{Verifying the extended model with empirical data}

\subsection{Parameters used in verification}

Now when our extension to the FAM-model has been introduced, it is applied to empirical data of industrial maintenance companies. Here we will present the modelling parameters used in this paper. In order to verify the connection between the $C C C$ and the return on equity, the other parameters of the extended model are set as constants. In this research, sample averages from the period 2004-2009 are used. Table 1 summarizes these averages.

\section{$<$ Table 1 here >}

There is a big difference between the SMEs and the large maintenance companies considering the length of the $C C C$. On the basis of the data, it seems that compared with the SMEs, the large maintenance companies benefit from both economies of scale and close cooperation with their host companies. The EBITDA\% is higher in the SMEs, but when the ROI is inspected, the situation changes because the large maintenance service companies operate with exceptionally light balance sheets. The debt-toequity ratios of the industry are very low, 0.08 for the large companies and 0.25 for the SMEs, and the interest rate of debt is quite high for both groups. This is because our extension to the FAM-model defines debt as long-term liabilities only, whereas in reality the analyzed maintenance companies had also a lot of short-term debt. The return on equity is significantly higher for the large companies. This is due to the higher values for the ROI, and lower values for the interest rate of debt. 


\subsection{Impact of the CCC on the return on equity}

Next, the parameters presented above are used to study the connection between the $C C C$ and the $i_{E}$. In Figure 2, the impact of the $C C C$ on the return on equity is presented. The average numbers of the companies from 2004 to 2009 are depicted with the vertical lines. The impact of the $C C C$ on the return on equity is very similar to the impact of the $C C C$ on the $R O I$ showed by Marttonen, Viskari, and Kärri (2011). This is reasonable, because the debt-to-equity ratios of the maintenance companies are exceptionally low. When the $C C C$ is very small or negative, the difference between the ROI and the interest rate of debt (see Equation (4)) is larger, causing an increase in the return on equity. It is also notable that especially large maintenance companies should pay attention to preserving their good return on equity through keeping the $C C C$ from growing uncontrollably. On the other hand, the potential for improvements is larger for SMEs, due to the higher value of the $C C C$.

\section{$<$ Figure 2 here $>$}

The $F A \%$ can be concluded to be the parameter having the greatest impact on the connection between the $C C C$ and the return on equity. For example, if the SMEs could halve their $F A \%$ to $10 \%$, the curve connecting their $C C C$ s to their $i_{E S}$ would be steeper. This is depicted in Figure 3. If the $F A \%$ of the SMEs were only $10 \%$, decreasing the $C C C$ from 52 days to 30 days would increase the $i_{E}$ of the SMEs by over 50 percentage points. With the actual, higher $F A \%$, the corresponding increase of the $i_{E}$ would be 25 percentage points. Thus the importance of broader company asset management should be emphasized, taking into consideration both fixed assets and working capital.

$<$ Figure 3 here >

\subsection{Impact of different financial positions on working capital management}

Now the connection between the $C C C$ and the $i_{E}$ is examined under dynamic financial conditions. Figure 4 shows the varying interest rate of debt and the debt-to-equity ratio of maintenance SMEs and large companies, respectively. The upper side of the figure presents the SMEs, while the lower side shows the large companies. The figure shows how the $C C C$ should develop in order to keep the return on equity unchanged. The grey circles illustrate the average position of the companies in 2004-2009. 
The model used in this paper links the debt-to-equity ratio and the interest rate of debt to each other, according to the traditional theory of cost of capital. On the other hand, Figure 4 has been constructed without any specific scenarios, by letting the interest rate of debt to develop independently of the debt-to-equity ratio. This way, the theory presented by Modigliani and Miller (1958) has not been abandoned, either.

\section{$<$ Figure 4 here >}

For SMEs, the changes of the interest rate of debt and the debt-toequity ratio cause extensive variation in the $C C C$. We can see that if the debt-to-equity ratio increased to 0.5 , the same $i_{E}$ could be achieved with a six days longer $C C C$. On the other hand, if the debt-to-equity ratio were decreased to 0.1 , the $C C C$ should be shortened by five days. The impact of the interest rate of debt on the connection between the $C C C$ and the $i_{E}$ is modest with low debt-to-equity ratios. However, the impact increases alongside the debt financing. Because the $C C C$ of the SMEs is quite long, it is possible for them to make the proportional changes required to keep the return on equity unaltered. The debt-to-equity ratio of the maintenance SMEs increased in 2004-2009. Yet, the average value was still low (0.25), and in theory the maintenance SMEs would gain financial leverage from increasing it. However, the average ROI of the SMEs was about $16 \%$, and if the interest rate of debt grows higher than that, the financial leverage is lost. Also the impact of the financial crisis must be noted. In 2009, the ROI of the SMEs was clearly negative.

The debt-to-equity ratio of the large companies was very low (0.08), and thus the main emphasis of the analysis was in increasing the share of debt in the capital structure of the companies. If the debt-to-equity ratio of the companies increased to 0.5 , the $C C C$ could increase by 11 days without the $i_{E}$ getting worse. In fact, the debt-to-equity ratio increased during 2004-2009. As the average ROI of the companies at issue was well over $30 \%$, the financial leverage to be gained through getting into debt was rather steady. However, it is possible that the financial downturn hit the large maintenance companies later on, consuming the profitability and the financial leverage potential. This could have altered the optimal capital structure of the companies significantly. It should also be noted that at the moment many companies are trying to avoid running into more debt. The financial crisis has shaken companies, and caution is taken regarding finance and capital structures. Thus the role of more effective working capital management is highlighted: decreasing the financial leverage 
causes the return on equity to reduce. New solutions are needed to appease the company owners.

\section{Conclusions}

This paper has illustrated how the return on equity can be controlled through effective working capital management. It can be concluded that the return on equity can be improved by shortening the cycle time of operational working capital. The managerial and financial perspectives of flexible asset management can be integrated through analytical modelling, as demonstrated in this paper. The impact of the interest rate of debt and the debt-to-equity ratio have also been taken into account. This way, we have included the dynamic financial conditions of the present day in the discussion. We conclude that changes in these conditions could be compensated through controlling working capital.

We have contributed to the academic discussion with two theoretical implications. First, we have provided an extended analytical model for flexible asset management. This model connects asset management to the perspective of the company owners through the return on equity. The topic is important, yet rather unexplored in academia. Secondly, we have shown that the amount of fixed assets relative to the net sales $(F A \%)$ has a large impact on the connection between working capital and the return on equity. Thus it is important to adopt a broader view on asset management: both working capital and fixed assets should be managed at the same time.

The impact of the $F A \%$ on the connection between working capital and the return on equity led us to the first of our three managerial implications: companies with a small $F A \%$ should manage their working capital actively. The impact of working capital on profitability is emphasized due to a light balance sheet. This holds for most service industries, and undoubtedly also for some manufacturing industries. Our second managerial implication is about the capital structure of a company: the debt-to-equity ratio affects the scale of financial leverage, and thus also the connection between working capital and return on equity. Basically, whenever a company makes its debt-to-equity ratio lower, financial leverage is lost. This causes some of the company owner's profits to disappear. The diminishing profits should be compensated somehow. Our conclusion is that working capital management is a worthy option for that. Our third and final managerial implication is related to the interest rate of debt: we have shown that the interest rate of debt has an impact on the connection between working capital and the return on equity. The impact is greater when the debt-to-equity ratio is higher. Thus especially in 
companies with high debt-to-equity ratios, effective working capital management can offer a solution to profitability changes caused by variation in the interest rate of debt.

We have derived our extended model for flexible asset management with some underlying assumptions. For example, it is important for companies to manage both their working capital and fixed assets. However, when a company has a really high amount of fixed assets, it is possible that the importance of working capital is only modest. In this case, the optimal parameters of the model could include something else than the $C C C$. This matter is included in our research limitations. Also, our research has been done on the company level, but the competition is transferring from being between companies into being between company networks. Thus it should also be analyzed how the changes in the working capital or asset management practices affect the other companies in the same network. Future research should focus on this as well. The interest in effective working capital management should be maintained in future research. After all, working capital management provides companies with opportunities that should not be left unexploited.

\section{References}

Black, A., Wright, P. and Bachman, J.E. (1998) In Search of Shareholder Value. Managing the Drivers of Performance, Price Waterhouse, London.

Blinder, A.S. and Maccini, L.J. (1991) 'The resurgence of inventory research: what have we learned?', Journal of Economic Surveys, Vol. 5 No. 4, pp.291 - 328.

Brealey, R.A., Myers, S.C. and Allen, F. (2008) Principles of Corporate Finance, $9^{\text {th }}$ ed., The McGraw-Hill Companies, New York.

Deloof, M. (2003) 'Does working capital management affect profitability of Belgium firms?', Journal of Business Finance \& Accounting, Vol. 30 No. 3-4, pp.573 - 587.

Deloof, M. and Jegers, M. (1996) 'Trade credit, product quality, and intragroup trade: some European evidence', The Journal of Financial Management Association, Vol. 25 No. 3, pp.33 - 43.

Demski, J.S. (2007) 'Analytic modeling in management accounting research', in Chapman, C.S., Hopwood, A.G. and Shields, M.D. (Eds.), Handbook of Management Accounting Research, Elsevier, Amsterdam, pp.365 - 371. 
Eriotis, N., Vasiliou, D. and Ventoura-Neokosmidi, Z. (2007) 'How firm characteristics affect capital structure: an empirical study', Managerial Finance, Vol. 33 No. 5, pp.321 - 331.

European Commission (2009). Definition of micro, small and mediumsized enterprises adopted by the commission. [online] Available from http://eur-

lex.europa.eu/LexUriServ/LexUriServ.do?uri=OJ:L:2003:124:0036:00 41:en:PDF (Accessed 6 May 2011).

Filbeck, G., Krueger, T. and Preece, D. (2007) 'CFO magazine's "working capital survey": do selected firms work for shareholders?', Quarterly Journal of Business \& Economics, Vol. 46 No. 2, pp.3 - 22.

Finnish Maintenance Society (2007). Maintenance in national economy of Finland. [online] Available from http://www.promaint.net/alltypes.asp?menu_id=348 (Accessed 5 May 2011), (in Finnish).

García-Teruel, P.J. and Martínez-Solano, P. (2007) 'Effects of working capital management on SME profitability', International Journal of Managerial Finance, Vol. 2 No. 3, pp.164 - 177.

Graham, J.R. and Harvey, C.R. (2001) 'The theory and practice of corporate finance: evidence from the field', Journal of Financial Economics, Vol. 60 No. 2, pp.187 - 243.

Harris, M. and Raviv, A. (1991) 'The theory of capital structure', The Journal of Finance, Vol. 46 No. 1, pp.297 - 355.

Hofmann, E. and Kotzab, H. (2010) 'A supply chain-oriented approach of working capital management', Journal of Business Logistics, Vol. 31 No. 2, pp.305 - 330.

Hull, R.M. (2011) 'Debt-equity decision-making with and without growth', Managerial Finance, Vol. 37 No. 8, pp.765 - 787.

Jensen, M.C. and Meckling, W.H. (1976) 'Theory of the firm: managerial behavior, agency costs and ownership structure', Journal of Financial Economics, Vol. 3 No. 4, pp.305 - 360.

Joshi, P.L., Kumar, R. and Al-Ajmi, J. (2011) 'An empirical study of the use and usefulness of financial, non-financial and subjective measures for performance evaluation in industrial companies in Bahrain', International Journal of Managerial and Financial Accounting, Vol. 3 No. 2, pp.140 - 169.

Kayhan, A. and Titman, S. (2007) 'Firms' histories and their capital structures', Journal of Financial Economics, Vol. 83 No. 1, pp.1 - 32.

Lambert, D. and Pohlen, T. (2001) 'Supply chain metrics', The International Journal of Logistics Management, Vol. 12 No. 1, pp.1 19. 
Leary, M.T. and Roberts, M.R. (2005) 'Do firms rebalance their capital structures?', The Journal of Finance, Vol. 60 No. 6, pp.2575 - 2619.

Losbichler, H., Mahmoodi, F. and Rothboeck, M. (2008) 'Creating greater shareholder value from supply chain initiatives', Supply Chain Forum: International Journal, Vol. 9 No. 1, pp.82 - 91.

Marttonen, S., Viskari, S. and Kärri, T. (2011) 'Modeling the impact of working capital management on the profitability in industrial maintenance business'. Paper Presented at the $6^{\text {th }}$ World Congress on Engineering Asset Management. 2-5 October 2011. Cincinnati, USA.

Modigliani, F. and Miller, M.H. (1958) 'The cost of capital, corporation finance and the theory of investment', The American Economic Review, Vol. 48 No. 3, pp.261 - 297.

Ojanen, V., Hatinen, L., Kärri, T., Kässi, T. and Tuominen, M. (2012) 'Flexible investment planning and collaborative maintenance management', in Van der Lei, T., Herder, P. and Wijnia, Y. (Eds.), The State of the Art in Europe from a Life Cycle Perspective, Springer, Dordrecht, pp.65 - 77.

Parsons, C. and Titman, S. (2008) 'Empirical capital structure: a review', Foundations and Trends in Finance, Vol. 3 No. 1, pp.1 - 93.

Shah, N.H. (2009) 'Optimisation of pricing and ordering under the twostage credit policy for deteriorating items when the end demand is price and credit period sensitive', International Journal of Business Performance and Supply Chain Modelling, Vol. 1 No. 2-3, pp.229 239.

Shin, H. and Soenen, L. (1998) 'Efficiency of working capital management and corporate profitability', Financial Practice and Education, Vol. 8 No. 2, pp.37 - 45.

Stretcher, R. and Johnson, S. (2011) 'Capital structure: professional management guidance', Managerial Finance, Vol. 37 No. 8, pp.788 804.

Talha, M., Christopher, S.B. and Kamalavalli, A.L. (2010) 'Sensitivity of profitability to working capital management: a study of Indian corporate hospitals', International Journal of Managerial and Financial Accounting, Vol. 2 No. 3, pp.213 - 227.

Viskari, S., Pirttilä, M. and Kärri, T. (2011) 'Improving profitability by managing working capital in the value chain of pulp and paper industry', International Journal of Managerial and Financial Accounting, Vol. 3 No. 4, pp.348 - 366.

Wang, Y.J. (2002) 'Liquidity management, operating performance, and corporate value: evidence from Japan and Taiwan', Journal of Multinational Financial Management, Vol. 12 No. 2, pp.159 - 169. 
The enterprises selected for the research

\begin{tabular}{lrr}
\hline Large enterprises & Personnel in & Net Sales in 2007, \\
& 2007 & 118.2 \\
\hline Fortek Oy & 858 & 83.4 \\
Varenso Oy & 473 & 78.9 \\
Konecranes Service Oy & 516 & 73.9 \\
Oy Botnia Mill Service Ab & 591 & 45.0 \\
Kymenso Oy & 743 & 399.4 \\
\hline Large enterprises in total & 3181 & Mersonnel in \\
\hline SMEs & 2007 & Net Sales in 2007 \\
& 104 & 12.5 \\
\hline ISS Teollisuuspalvelut Oy & 53 & 9.4 \\
Tespal Oy & 92 & 8.4 \\
Machinery Service Finland Oy & 109 & 7.0 \\
Sahala Industrial Services Oy & 50 & 6.3 \\
Pikoteknik Oy & 103 & 5.5 \\
Tormets Oy & 25 & 3.9 \\
Mahro Oy & 48 & 3.1 \\
Betamet Service Oy & 46 & 2.6 \\
Astepa Oy & 36 & 2.6 \\
Metso Mill Service Kauttua Oy & 16 & 2.2 \\
Kangasalan Pajaservice Oy & 20 & 0.8 \\
JTT Konepaja Oy & 10 & 72.6 \\
Rauman Sähkökonehuolto Oy & 712 & 472.0 \\
\hline SMEs in total & 893 & \\
\hline All enterprises in total & & My \\
\hline
\end{tabular}


Figure 1 Connecting the managerial and financial view of working capital management

The Managerial View

The Financial View

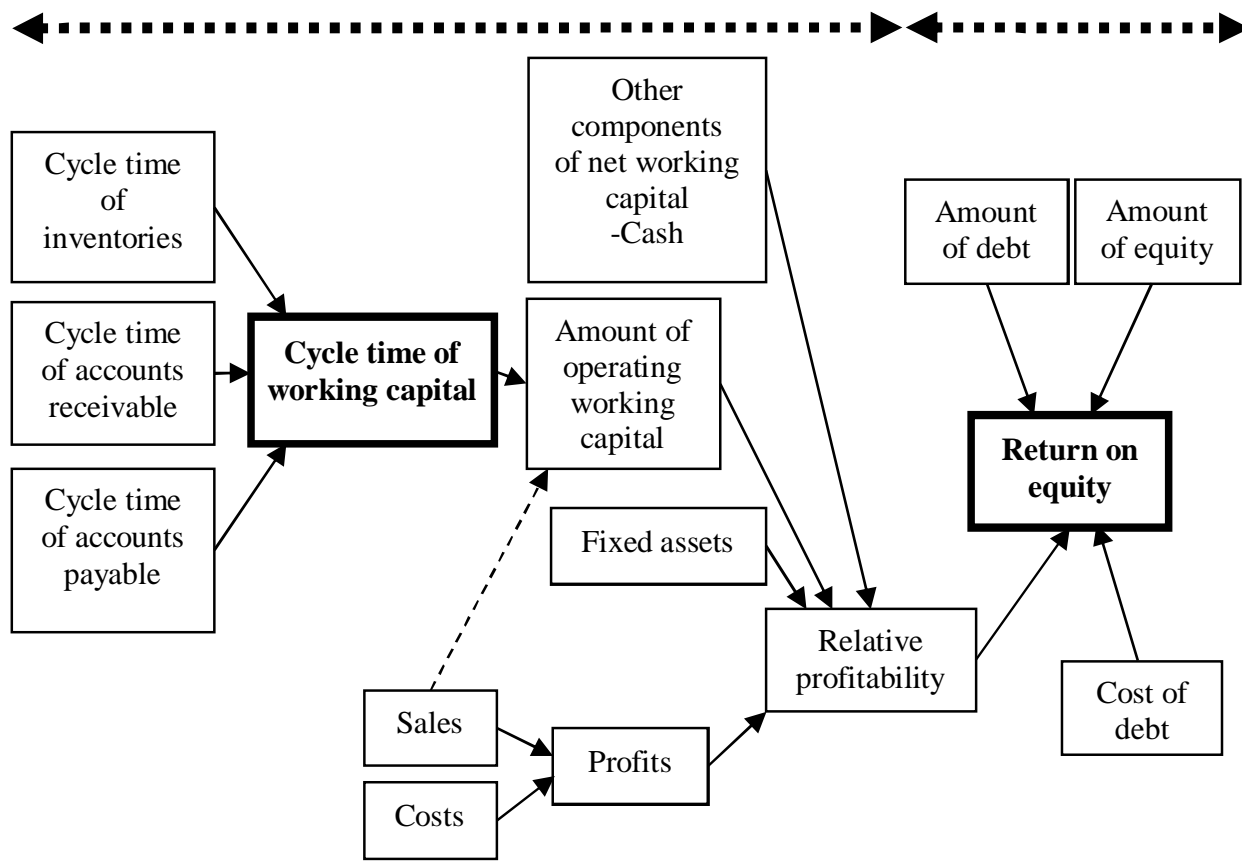

Table 1 Parameters of the maintenance companies used in the modelling

\begin{tabular}{|l|r|r|}
\hline & \multicolumn{1}{|l|}{ Large } \\
& SMEs & \multicolumn{1}{l|}{ companies } \\
\hline$C C C$, days & 52 & 11 \\
\hline$E B I T D A \%$ & 7.7 & 5.5 \\
\hline$F A \%$ & 20.7 & 7.1 \\
\hline$B$, years & 8.4 & 6.6 \\
\hline$r$, days & -8.1 & 9.0 \\
\hline$R O I, \%$ & 15.2 & 33.9 \\
\hline$D, €$ & 301000 & 650000 \\
\hline$E, €$ & 1207000 & 8469000 \\
\hline$D / E$ & 0.25 & 0.08 \\
\hline$i_{D}, \%$ & 10.3 & 9.9 \\
\hline$i_{E}, \%$ & 16.4 & 35.7 \\
\hline
\end{tabular}


Figure 2 Impact of the CCC on the return on equity in maintenance SMEs and large companies

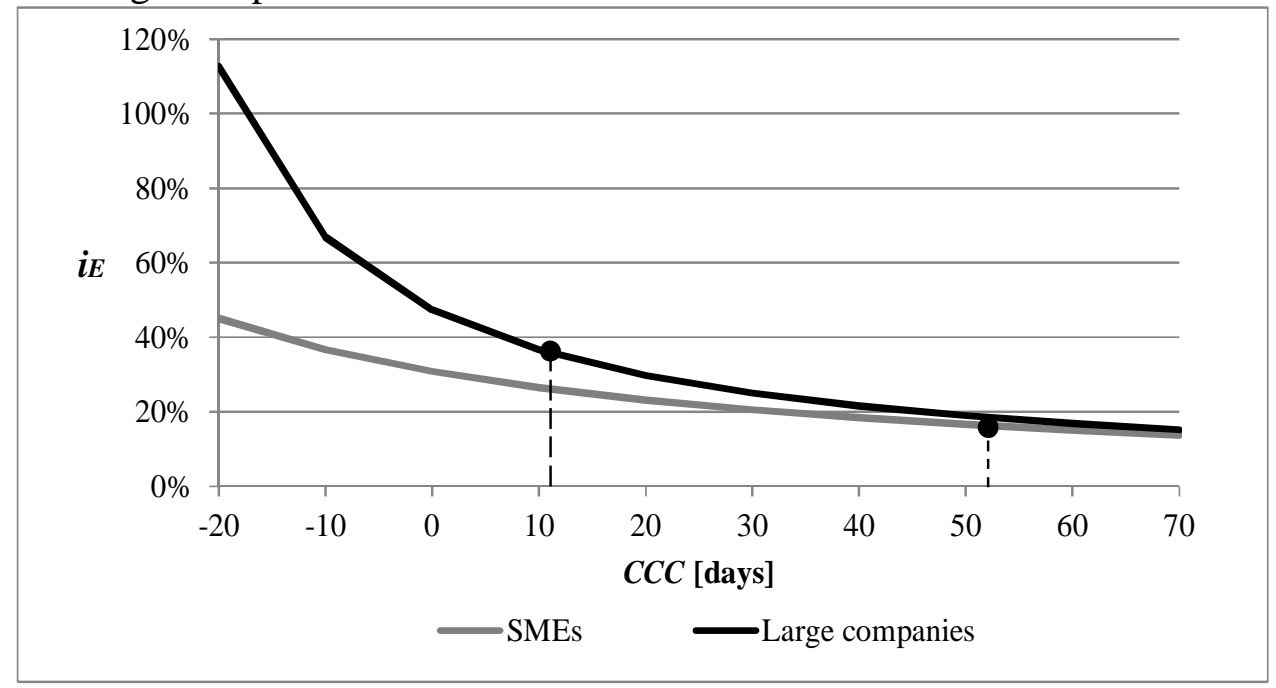

Figure 3 The impact of the FA\% to the connection between the CCC and the return on equity in maintenance SMEs

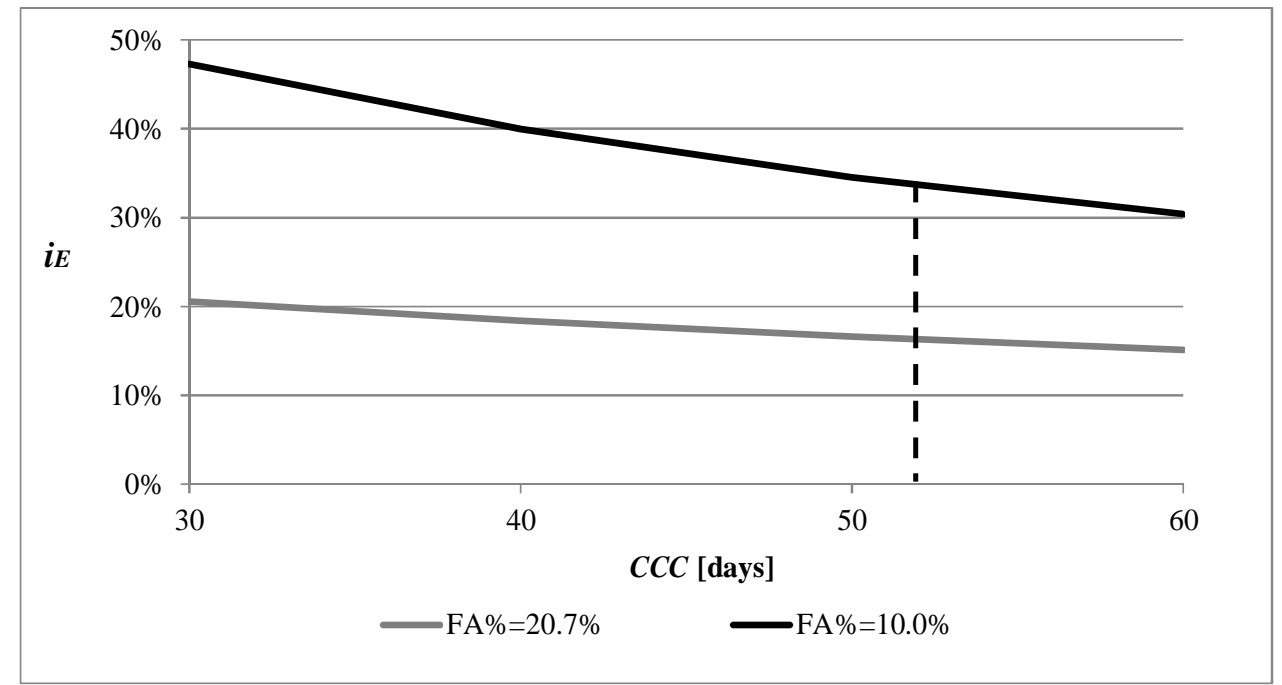


Figure 4 Length of the CCC required to keep the return on equity unchanged when both the interest rate of debt and the debt-to-equity ratio vary

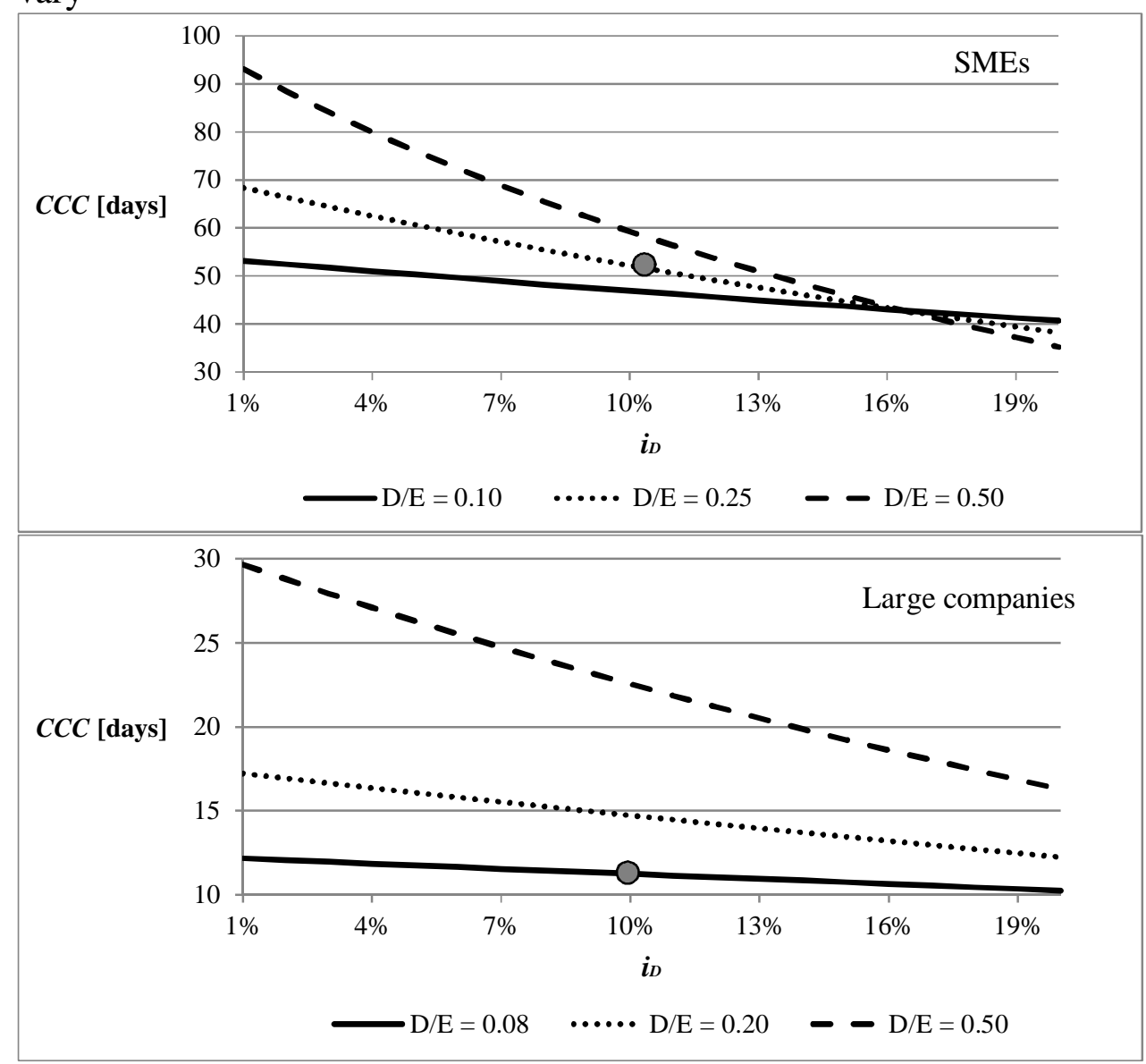

